\title{
The shift towards democratic governance: System change versus regime change analysis in The Gambia 2017-2019
}

\section{Pergeseran menuju tata pemerintahan demokratis: Analisis perubahan sistem melawan perubahan rezim di Gambia 2017-2019}

\author{
Sunkung Danso ${ }^{1} \&$ Sulikah Asmorowati ${ }^{2 *}$ \\ ${ }^{1}$ Program Officer, Institute for Human Rights and Development in Africa \\ ${ }^{2}$ Department of Public Administration, Faculty of Social and Political Sciences, Universitas Airlangga \\ Address: ${ }^{1}$ Brusubi 949, Banjul, Gambia \\ ${ }^{2}$ Jalan Dharmawangsa Dalam, Airlangga, Surabaya, East Java, Indonesia 60286 \\ E-mail: sulikah.asmorowati@fisip.unair.ac.id
}

Article History: Received 6 June 2020; Accepted 23 September 2020; Published Online 26 October 2020

\begin{abstract}
Democratic governance has been seen as a catalyst for inclusive growth and meaningful development in many countries. Shifting from authoritarian rule to more democratic rule has also been seen as essential for many governments worldwide. Democratic governance is often a problem for developing countries, including most African countries and particularly The Gambia. This paper analyses the shift towards a more democratic governance style that is heated debated in The Gambia. The debate started when one of the coalition government members asserted that they could achieve regime change; however, a democratic system change remains lacking. This paper has sought to analyze whether the shift toward a more democratic leadership style in The Gambia is one of system change or regime change and ascertain what has democratically changed and bad governance in the new government. This article's main objective is to create political awareness and enlighten the readers on the change's misconceptions towards democratic governance. The discussion focuses on democratic governance and the collective action theory of governance to explain the democratic process in New Gambia. This study adopts qualitative case study research methods; the research employed a systematic review of the existing scholarly journal articles, books, newspapers, and television interview recordings. The observation used to identify, understand, and interpret the democratic governance situation in The Gambia from 2017 to 2019. The findings show that the coalition government has succeeded in achieving a democratic regime change; however, the democratic system change itself is too slow, or it is not happening. For the first time in The Gambia's history, a seating president defeat through the ballot box. In conclusion, the democratic governance system change is far-fetched. It is vital to state that there is little or no difference between Jammeh's regime and the current regime under President Barrow's leadership. The same problems continue to persist. Finally, the transparency and accountability mechanisms must be enhanced to address the endemic problem of corruption.
\end{abstract}

Keywords: democratic governance; democratic system change; democratic regime change; governance; democracy; The Gambia

\begin{abstract}
Abstrak
Tata pemerintahan yang demokratis telah berperan penting dalam mendorong pertumbuhan inklusif dan pembangunan di berbagai banyak negara. Karena itu, pergesaran dari pemerintahan otoriter ke pemerintahan yang lebih demokratis dipandang perlu bagi banyak pemerintah di dunia. Meskipun demikian, tata pemerintahan yang demokratis sering menjadi masalah bagi negara-negara berkembang, khususnya di sebagian besar negara-negara Afrika, khususnya Gambia. Artikel ini menganalisis pergeseran menuju pemerintahan yang lebih demokratis di Gambia yang banyak memantik perdepatan selama periode 2017-2019. Persoalan bermula ketika salah satu anggota pemerintahan koalisi menyatakan bahwa mereka mampu mencapai perubahan rezim, namun tidak disertai pergerseran pada sistem demokrasi. Artikel ini berupaya untuk menganalisis apakah upaya mewujudkan pemerintahan demokratis di Gambia merupakan salah satu perubahan sistem atau perubahan rezim. Artikel ini bertujuan untuk menciptakan kesadaran politik dan menyajikan analisa tentang kesalahpahaman perubahan menuju pemerintahan yang demokratis. Diskusi berfokus pada tata pemerintahan demokratis dan teori tindakan kolektif pemerintahan untuk menjelaskan proses demokrasi di
\end{abstract}


Gambia Baru. Penelitian ini menggunakan metode penelitian studi kasus kualitatif dengan tinjauan sistematis artikel jurnal ilmiah, buku, surat kabar, dan rekaman wawancara televisi. Observasi juga digunakan untuk mengidentifikasi, memahami dan menafsirkan situasi pemerintahan demokratis di Gambia dari tahun 2017 hingga 2019. Penelitian ini menemukan bahwa pemerintah koalisi telah berhasil mencapai perubahan rezim demokratis tetapi perubahan sistem demokrasi terlalu lambat atau tidak terjadi. Untuk pertama kalinya dalam sejarah Gambia, presiden yang berkuasa dikalahkan melalui kotak suara. Penelitian ini menyimpulkan bahwa perubahan sistem dari rezim otokratis ke pemerintahan yang lebih demokratis telah terjadi. Lebih lanjut, sangat sedikit atau bahkan tidak ada perbedaan antara rezim Jammeh dan rezim yang berkuasa saat ini di bawah kepemimpinan Presiden Barrow. Masalah yang sama pun terus berlanjut, karena itu sudah cukup untuk saling menyalahkan dan mulai bekerja untuk negara. Gambia membutuhkan pemimpin yang kompeten dan pelayan masyarakat yang akan melindungi konstitusi Gambia dan memajukan negara, dan yang terpenting, mekanisme transparansi dan akuntabilitas harus ditingkatkan untuk mengatasi masalah korupsi.

Kata kunci: pemerintahan demokratis; perubahan sistem demokrasi; perubahan rezim demokratis; pemerintahan; demokrasi; Gambia

\section{Introduction}

The Gambia in December 2016 was hence a profoundly impossible setting for the vanquish of the incumbent in presidential races. It took nearly everybody by surprise when on $2^{\text {nd }}$ December 2016 , the Electoral Commission of The Gambia pronounced opposition candidate Adama Barrow to be the winner of the election (Hartmann 2017). It spells the end of dictatorship in The Gambia and a shift to democratic rule of governance. For 22 years, Jammeh's authoritarian rule has slow down the development of The Gambia in many ways and neglected the importance of a democratic system that has a high prospect for inclusive growth and development. According to Saine (2009), the democratic system of government and open economies developed much quicker than those that remained closed economies and dictatorial. It has highlighted that a democratic system of governance and open economies have higher chances for growth and development.

Democracy is a government system in which the power resides in people, and legitimacy gave to a group of individuals called politicians to run the state of affairs of a nation at a particular time. Democracy refers to a government of the people. Abraham Lincoln (1809-1865) stated that democracy is the government of the people, people, and people. Thus, democracy emphasizes citizens' full participation in which they have to right to vote or be voted; however, some political theorists stressed that democracy is more than just periodic elections and multiparty competition. Indeed democracy is a whole system that requires different processes and involves different actors in the country's political affairs. It will be right to state that sovereignty resides in people, and it gives the right to the people to choose and oust rulers through the ballot box. It was alluded by one of the democratic scholars named Tocqueville (1805-1859). They visualized popular sovereignty as directly exercised by and with the people through their participation in self-governing politics institutions at all levels of society, not just in national elections (Gellar 2005). Based on this argument, it is evident that democracy is crosscutting issues. The democratic principle is limited to the elections process, and a governance system that includes popular participation in decision-making, respect for the rule of law, transparency, and accountability.

The concept of governance has been around since the beginning of human civilization and is a process of handling a country's affairs state or an institution following democratic principles, norms, and values. It comprises a self-governing system or an organization, adhering to the law, ensuring accountability and transparency - the idea of governance collectively understood around the state, government, and other organizations; however, governance involves decision making and how those decisions are being implemented. In addition, the concept applies to different works of life, such as to cooperate governance, local governance, regional governance, national and international governance. Chhotray \& Stoker (2009) explain that governance seeks to understand how we construct collective decision-making. Therefore, governance is both a process and a system because of its application 
to decision making and implementation. Good governance is one of the democratic principles of governance, and the practice is to exercise decorum in public administration through transparency, accountability, openness, the rule of law, and public participation. Thus, governance operates at a higher level to govern and administer to ensure that the government provides services that positively impact people's lives. It is what is referred to as the public sector, and it is not expected to work in isolation but rather with the private sector since it cannot do all alone. Chhotray \& Stoker (2009) defined governance as is about the rules of collective decision-making in settings where there is a plurality of actors or organisations and where no formal control system can dictate the terms of the relationship between these actors and organisations. This definition encapsulates four compounding words or issues such as rules (procedures in the decision-making process, either formal or informal), collective (widespread participation in decision making), decision-making (strategic involvement of state and non-state actors in the decision-making process) and no formal control system to dictate the relationship and outcome (civic liberty to participate in the decision-making accordingly).

In essence, governance is a government system that is governed by the rule of law and order. There are different governments, starting from the central government to the local government to provide goods and services to the people at all levels. A good government, an integral concept of governance, implies a high level of organizational effectiveness concerning policy formulation and implementation, especially in economic policy and its contribution to growth, stability, and popular welfare. In summation, it is befitting to assert that governance is a rational concept that enhances the interaction between the states and social actors and social actors themselves (Loum 2002). Saine (2009) reaffirmed that a democratic governance system is a catalyst for inclusive growth and development. Furthermore, a democracy advocate's governance system checks and balances for both national and international organizations. It argues that international organisations and influential states have increasingly sought to hold both existing and emerging states accountable for their treatment of constituents using standards of governance defined in terms of human rights and democracy (Gardner 2011). The fundamental question worth asking in a discourse of this nature is a distinction between the democratic system and regime.

Firstly, let define what a system is and a regime. According to MacMillan Dictionary (2020), a system defined as a set of interconnected things that works together for a common purpose. For example, there is a democratic system of government or a solar system. The same dictionary defines a regime as a government that controls a particular country for a while, especially in strict or unfair ways, for example, military rule and dictatorship. Therefore, system change requires government change into a more functional democratic system of government, while regime change refers to change in the executive or presidency of a government with all other state apparatus remaining unchanged. Lagerspetz (2016) proposed a list of conditions necessary for a good or working democracy. Lagerspetz (2016) further argued that democracy is a system of governance in which there is a correspondence between acts of governance and citizens' preferences, and the corresponding results from a process such as; political equality, responsiveness, equal and effective liberty, equal control of agenda, popular sovereignty, and constitutional entrenchment. The above statement reiterates that the democratic system of governance involves all stakeholders in the decision-making process, and it advocates for fairness and impartiality in public service delivery.

In essence, regimes come and go while the systems stay; however, the system can also change from being democratic to authoritarian or dictatorial as it was in The Gambia's case. The self-perpetuating rule issues should be a concern for every Gambian wherein our leaders overstay in power should change to a minimum period possible. In 52 years from independence, The Gambia has only two presidents. It is high time; our government starts fearing the people instead of people fearing the government because the power vested in the people can impeach the president according to due process. This research seeks to answer two fundamental questions: what democratization has changed and has not to change. The research will also highlight discussions on the current government's actions that contradict the rule of law and good governance practice. 


\section{Research Method}

This research adopts qualitative and case study methods. It argued that qualitative data generally expressed in words rather than numbers. The study of human beings and their societies and cultures requires many observations to identify, understand, and interpret ideas, customs mores, beliefs, and other essential human activities and attributes (Walliman 2006). In that regard, this study uses observation as events unfold from 2017-2019 in The Gambia to identify, understand, and interpret the idea of democratic change in The Gambia to understand the state of affairs in the country regarding democratic governance. It helps to examine the change that the nation is yearning for, moving from self-perpetuating rule to democratic governance and establishing what has changed. By concentrating intensively on observing a specific person or interaction, we sometimes can discern systematic or regular relationships among observations, and these, in turn, can provide the impetus necessary for developing a testable proposition (Crano et al. 2015). A specific case of shifting from authoritarian rule to democratic governance to analyze the change that occurs in the 2016 presidential election discussed. It generates detailed information about the democratic transition and how this democratic change is progressing to attain the citizenry's desires and aspirations.

Discussion and analysis in this article will use the collective action theory to explain governance. It is of paramount importance to state that the conceptualization of governance depends on understanding how different ways of developing rules and norms to interact and make collective decisions and maintained them (McKelvey et al. 2019). The main objective is to create political awareness and enlighten the readers on the misconceptions of democratic governance. This study will use a systematic review method of journal articles, books, newspapers, television interview recordings, and observation. Therefore, the source of information is from scholarly journal articles, books, and local newspapers; to systematically discuss the democratic governance situation. Important to state that the primary source to use for a literature review is the scholarly journal. It filled with peerreviewed reports of research. One can rarely find these journals outside of college and university libraries. Recall that most researchers disseminate new findings in scholarly journals (Neuman 2014).

\section{Result and Discussion}

Democratic governance buttresses the modern state is changing nature, highlighting the consequences of these changes on democracy. Bevir (2010) argued that democratic governance dates back to the rise of modernist social science, and it is fundamental to state that total inclusion is a bone of contention in democratic governance. Herein institutions will have different roles and objectives but must involve people in the policy process and policy implementation. According to modernist theories of governance, the cracks in representative institutions can be papered over by policy expertise (Bevir 2010). Furthermore, governance as a paradigm shifts citizens' role from passive to active participants in democracy. Democracy is here conceived as a regime or a government system in which rulers are held accountable for their actions in the public domains by citizens acting indirectly through their representatives' competition and cooperation (Mudacumura \& Morçöl 2014). Governance advocates for popular participation in the decision making process and ensure accountability and transparency in public service delivery.

Democratic governance advocate for efficient and open administration, which encourages popular participation in the decision-making process and competition in the market, while collective action theory observes group behaviour in the quest to achieve an end; therefore, collective action theory will be used to examine governance in the new democracy of The Gambia. It will help to broaden the understanding of governance in the democratic system of governance. When the discussion arose around governance, two keywords keep coming: transparency and accountability, good governance characteristics in a functioning government. One may wonder what governments accountable and transparent for what? Human actions contravened to changing situations and progressive moves in the world. Occasionally, human actions are misguided by emotion and passion for the regarded ideal. The truth of the matter is that not everything that matters counts as well as not everything that counts matters. 
Olson (1965) first mentioned collective action theory, and he describes it as a group of people coming together to create or provide a public good; however, it is used in governance to prescribe the people's involvement in the decision-making process either in an organization or government. It is vital to note that governance theories are analytical lenses that help us understand our contemporary world and have different purposes. Further stressed that some of them focus on how different actors, jurisdictions, levels, and institutional arenas interact to exchange knowledge and ideas, coordinate actions, and collaborate in making the definitive decision that produces collective outcomes (Ansell \& Torfing 2016). Further, it is essential to note that democratic governance expected to represent all citizens (Axtmann 2003). It is why democracy is described by many as the people's government, people, and people. Vehemently, people are crucial in the governance process, and citizens are at the centre of democratic governance since power resides in them, while legitimacy is given to few to govern the country's state of affairs according to statues.

Moreover, it is clear from the statement above that governance is a collective action, and precisely it helps the government system function effectively and efficiently. Furthermore, good governance tends to refer to the endeavours of international organizations such as the United Nations and the World Bank to assess and measure the quality of governing institutions in developing countries in terms of their stability, interaction, transparency, responsiveness, procedural fairness, effectiveness and adherence to the rule of law (Clark 2006, Frederickson et al. 2012). These mechanisms used to assess the government system's viability, and it is through this mechanism, the citizens can hold the public officials accountable. For example, in December 2018, the government of The Gambia under President Barrow has requested for a supplementary budget of about 25 million GMD and people rose against it, and the parliament subsequently rejected it.

Collective action theory is any form of the organized social or political act carried out by a group of people to address their needs or achieve something that they cannot achieve individually. For an instant, the oppositions went to poll with Yaya Jammeh four times, and he always defeats them with a simple majority according to constitutional dictates; however, in 2016, when the opposition parties came together to formed a coalition, they defeated the incumbent for the first time in the history of The Gambia. Virtually any form of organized group effort to address some form of inequality may be considered collective action. For example, the United States' civil rights movement in the 1960s is a classic example of collective action that advocates for equality in The United States society. According to Albers (2005), cooperation was defined as the joint performance of an activity by at least two actors so that the actions undertaken by one actor extendedly facilitate the actions of another actor. The collective dilemmas emerge from interdependence that payoffs to one individual depend on the decisions of others. Solving collective dilemmas requires changing individual decisions through governance arrangements that alter individual payoffs and result in a joint outcome that leaves at least one individual better off without harming any other individuals (Ansell \& Torfing 2016). From this statement, it will be correct to mention that human actions are interdependent, making us political animals. We always seek satisfaction; however, collectively, we tend to look for commonalities and respond accordingly. It argued that even a very brief overview of the complexities of cooperation exposes the pairwise fitness transaction model (Birch 2012). This model explains the connection between assets and entities, including partnerships, individual taxpayers, and trusts.

Arguably, collective dilemmas are at the heart of most real-world governance challenges, including environmental, health, education, foreign aid, and other policy domains (Ansell 2008, Ansell \& Torfing 2016). It is evident in real-life because we tend to undergo calculative thinking that if something unusual happens, what should be done next, and how should it be handled? It is always the case that the issues of resilience came into being in the development sphere and policy discourse so that governments can formulate a policy that is of great benefit to humankind and gives no room for uncertainties. It is only through this people can quickly recover from shock and stress.

In addition, human desires are unlimited, and the resources to satisfy those desires are said to be limited. Therefore, political economists focus heavily on problems like public goods provision (Olson 1965) and standard pool resource management (Ansell \& Torfing 2016). There is always 
confusion about who should own what and in what quantity from the collective action perspective; governance attempts to solve these different types of dilemmas by creating institutional arrangements that redefine the payoffs from individual behaviour and incentivize cooperation through top-down mandates or encourage bottom-up self-organizing (Frederickson et al. 2012, Pal 2012). Many social scientists seem to favour the bottom-up approach to governance and public administration, emphasizing the devolution of decentralization and popular participation.

Furthermore, governance is a multi-level process that creates monitoring mechanisms, punishes defection, rewards cooperation, provides information, fosters trust-based reciprocity, and attempts to create the conditions that make collective action likely to occur (Bache \& Flinders 2004). Effective governance requires an institutional framework that positively alters individuals' payoffs from cooperation and facilitates effective monitoring and enforcement of the rules if and when someone chooses to defect. Sometimes, there are little or no punishments if the individual chooses to defect; however, to some extent, it will not help the person's relationship with some other members of society. Two collective dilemmas that commonly affect public policy are the efficient production and effective management of public goods and common-pool resources. In the absence of a coordinating governance arrangement, collective goods will be under-provided when private individuals cannot fully capture the positive externalities of the provision or over-provided when private individuals cannot entirely exclude negative externalities from the exploitation of a common pool resource.

How classical philosophers and classical economists envisioned collective dilemmas impacted modern societies' governance arrangements to provide public goods and successfully manage common-pool resources. Aristotle argues that Socrates' vision of a democratic state that shares all property in standard and holds a unity of purpose is impractical (Ansell \& Torfing 2016, Campbell 2014). Instead, Aristotle famously argued that what is common to the most significant number gets the least amount of care (Ansell \& Torfing 2016, Campbell 2014). The collective dilemma envisioned by Aristotle was that of agreeing to a constitution that creates a community, which is necessarily familiar to all citizens but in which individuals can still hold private ownership of the household (Pal 2012). Thomas Hobbes wrote of the need for a strong central authority known as the Leviathan to prevent a state of nature, called war, and such a war as is of every man, against every man (Ansell \& Torfing 2016). There is some power struggle or struggle for control of resources; this brings conflict between the have and have not. To Hobbes, humans' behaviour or actions require a coordinating mechanism to achieve collective action, the benefits of which justify the loss of individual freedoms.

Through human inquiry, shared understandings can be built, ways of living alongside each other, and doing things together can found, problems can be solved, conflicts resolved, power imbalances can be challenged (Burns \& Worsley 2015). Market mechanism versus coercive government mechanism is the collective action of the private and public sectors. The government is very flexible when dealing with the private sector, and the mechanisms generally considered mutually exclusive. Federalists argued that the central government should coordinate the provision of some public goods like stable political order; however, it also advocated decentralized governance to provide other public goods. Tocqueville's belief in the role of decentralized governance and Tocqueville trumpeted communitybased governance, which is composed of voluntary cooperation and mutual respect (Ansell 2008, Ansell \& Torfing 2016). It is a voluntary action of whoever has the capability or expertise to join, and the sole aim is to provide the needs of the people. It is to note that the scramble for the limited resources instigates rivalry between groups, and different interest groups want to have more influence than others, and the elite class wants to maintain the status quo.

In some cases, this helps the consumers to have choices because it encourages competition. Even those living in poverty can choose the messages they will respect and modify them according to their preferences (Verwimp 2013). Based on Ansell (2008), Ansell \& Torfing (2016), Reisman (2015), it is a summary of the collection action theory and its characteristics:

"Samuelson explored the nature of collective goods by grouping goods into two categories: private goods are those rivalrous in consumption, and public goods are those non-rivalrous in consumption. Olson challenged long-held tenets of sociological group theory that assumed 
rational individuals with a common interest would necessarily act toward that common interest. Olson has a contrary option to the above statement. Olson claimed that individual rationality would lead to cooperative behaviour unless the number of individuals in a group is quite small, or unless there is coercion or some other special device to make individuals act in their common interest, rational, self-interested individuals will not act to achieve their common or group interests."

Governance advocates for the citizenry's full participation in the decision-making process, and it also guarantees civil liberty and respect for the rule of law in which human rights enshrine. The fundamental human rights promulgated in the democratic governance system.

\section{Governance in The Gambia}

The Gambia gained its independence from Great Britain in 1965 and became a republic on $24^{\text {th }}$ April 1970. Since then, the government changed twice, and the first change occurred through a military coup, which resulted in overthrowing the legitimate and constitutional government on $22^{\text {nd }}$ July 1994. Sir Dawda Jawara was the first president Republic of The Gambia, and he ruled for thirty years in multiparty democracy. His government characterizes with respect for human rights and democratic norms and values. As Loum (2002) mentioned, the government of Jawara has an excellent human rights record, and The Gambia was, in many ways, a shining example of multiparty democracy. Corruption was deeply rooted in his government, and several ministers accused of corruption; however, nothing is done to bring them to justice (Loum 2002). Jawara set up commissions and investigative panels to look into matters surrounding corruption allegations; however, none of the commissions and investigative reports' recommendations implements to the core (Loum 2002). Sallah (1990) pointed that corruption among highly placed officials and private businessmen become so visible that the alleged; were refer to as "The Banjul Mafia," a label that captured the means employed by those who control a substantial portion of the country's wealth in their pursuit of various private sinecures. Also, it was stated by Loum (2002) that apart from the neo-patrimonial nature of the People Progressive Party (PPP) regime, the Jawara government's reputation among Gambians further damaged by continuing allegations of corruption by cabinet ministers and civil servants in the government (Loum 2002). Many people believed that corruption is one reason why the $199422^{\text {nd }}$ July coup happened because of the weak institutions.

On Friday, $22^{\text {nd }}$ July 1994, a group of militaries with lieutenant's rank waged a coup to unseat a democratically elected president. This $22^{\text {nd }}$ July 1994 coup regard as a bloodless coup d'etat (Saine 2009). They suspended the constitution, introduced a decree, and established the Armed Forces Provisional Ruling Council (AFPRC), which Yahya Jammeh was the chairperson. It later changed to a political party called Alliance for Patriotic Reorientation and Construction (APRC), which ruled for 22 years in four consecutive elections. Since then, the military instituted themselves to power for 22 years with iron fist and tyranny. The regime became dictatorial since President Jammeh no longer adheres to the country's constitutional dictates, and he kept changing the constitution to suit his interests. The "two term-limit" remove from the constitution, and the $50+1$ clause changed to a simple majority without following the due processes. It means that for one to emerge as the winner of the presidential election, the person must have $51 \%, 50+1$. Absolute majority because his government succeeded in instilling fear of death in people through disappearance without trace, and no one dared to challenge his government power. Several individuals disappeared during this period in question. In addition to the series of atrocities committed, the regime is widely regarded by many as undemocratic, brutal dictatorial, full of cross violations of human rights, corrupt to the core, amongst other things.

Gambians decided to vote former President Jammeh out of power. Jammeh rules The Gambia for 22 years in a divide and rule system with an iron fist. Jammeh's regime is labelled dictatorial, authoritarian, and undemocratic. There were several cross violations of human rights and disregard for the rule of law. Jammeh, who came to power in 1994 with a bank overdraft, became more prosperous than the country by 2016 . He monopolized certain economic activities for his gain and drastically altered the 
constitution to venture into different categories of businesses wherein he established Kanilai Family Farm Group, which conducted several businesses across the length and breadth of the country. The power of wealth is in the people's hands, while civil servants continue to receive meagre salaries, which gave room for corruption; however, ex-president Jammeh became the most corrupt person in the government (Jeffang 2019).

On the $1^{\text {st }}$ December 2016, Gambians went to poll to vote for presidential terms in different ways. Seven opposition political party leaders and one independent candidate came together to formed a coalition. On $2^{\text {nd }}$ December 2016, the incumbent Jammeh defeated, and he accepted the election results, thereby called the opposition coalition leader Adama Barrow to congratulate him on his victory, which took many Gambians by surprise. A week later, Jammeh declared on $1^{\text {st }}$ December results as null and void because he got some information that some of his party members denied to vote, which misrepresented the results and asked for a fresh election. It did not go well with Gambians, and as such, the opposition coalition leaders emphatically recommended that if the incumbent has any discrepancy against the election results; it should be the channel to the high court and the issue will be dealt with according to law. The issues were dragged up to a month until The Gambia Constitution's time for the newly elected president to take office. Because the defeated presidency was reluctant to relinquish power, the new president has sworn in Dakar, Senegal, and at the Gambian Embassy, which is considered a Gambian territory according to international law. Two days later, the former president Jammeh went on exile in Equatorial Guinea, and the new president returns to The Gambia and assumes his office as the president of The Gambia. Currently, The Gambia is in the transition from dictatorial rule to democratic rule, and the proper management of transition is fundamental to the ushering in meaningful growth and development.

In light of the above developments in the political arena, system change and regime change took centre stage in media and public debates in every part of The Gambia. The debate grew broad and intense when one of the opposition leaders was asked what did the coalition government achieve so far and replied by claiming that they succeeded in regime change but not system change; it is still a challenge, which is a gradual process. The government of The Gambia in 2017 made a press release to debunk his statement.

The government's first violation of the constitution is from the very beginning when they took office and changed the constitution's age limit without following the due process. The country was without a vice president for a month plus, which resulted in the government changing some constitutional provisions without following the due process to suit an individual intended for the vice president's position. It made the electorates doubt whether the government will remain adherent to law and respect the national constitution. Therefore, people began to question the government's credibility to respond to the needs of the people. For some, this government is like old wine in a new bottle. According to the President of The Gambian Farmers Association in News Broadcast by King's FM Radio (2019), Jammeh's government is far better than that of Barrow led government in terms of its support to farmers and buying farm produce. In the same vein, Ceesay, a political science lecturer at the University of The Gambia, in an interview with The Voice Newspaper as cited in Wally (2018), the president needs to earn the confidant of The Gambia National Army and also asserted that the presence of ECOWAS and Military Group (ECOMIG) in the country might not prevent long-term security risk. It does not go well with the government, and a few days later, he was invited for questioning at The Gambia Police Force Headquarter in Banjul, wherein he was detained overnight in connection to the statement, as mentioned earlier.

Furthermore, a group of Gambian experts was engaged by Chronicle (2019), to sound their opinion about the status of The Gambia since President Barrow took office. Speaking therein, Ceesay clearly stated that The Gambia is experiencing something called democratic backsliding. According to Ceesay in Chronicle (2019), during Jammeh's era, people lost hope in the government and thought nothing could be done to resolve The Gambia's deeply rooted political problems. There comes 2016, people get hope in the new government, thinking that things will change as expected; however, what we are witness quite contrary to the hopes and expectations of the Gambians. He fears the rate in 
which people's hopes and aspirations have subsided in the government, which is very dangerous. People are indeed free to speak; however, what are we speaking? It is an essential question because people are just speaking against each other or engaging in attacking other people's personalities instead of engaging in productive discussions. We are not discussing ideas that can move the country forward but rather a tribal sentiment. The Gambia has many problems that we need to interrogate and provide practical solutions to those problems. In a similar engagement, a journalist asked Coach Pasamba Jow (an activist):

"Where does the problem lie?"

In his response, Jow said:

\begin{abstract}
"When we went to the polls in 2016, the fundamental objective is to have a new beginning; however, what we have got instead is a government that is interested in more of entrenching themselves to power rather than addressing the needs and aspirations of the Gambian people. We now have a government that is pretty much backsliding towards Jammeh's regime. Any government that is protecting itself from her citizenry is going towards tranny. Whether the water cannon they bought recently or whatsoever, it is all geared towards restricting the democratic space in the country."
\end{abstract}

To re-affirm these statements made by Coach Jow, later 2019, the minister of justice brought before the National Assembly Members a draft criminal offence bill 2019, which criminalized insult directed to the president or his parents or any public official. The president's interest in entrenching himself to power has been confirmed to many Gambians in several presidents himself's utterances. After one year in office as the Republic of The Gambia president, President Barrow took office he paid a state visit to Turkey in 2018. While on the state visit, Barrow granted an interview with Josh (2017) on TRT World News channel, and he was asked:

"If you look into young Gambians' eyes today, what would you tell them is your plans for them?"

In his response, Barrow said:

"We have to build a strong foundation, and we have to win people's confidence."

Then the journalist further asked:

"How long will that take?"

In Barrow's reply, he highlighted some of the development programs his government intended to implement and end his statement with even five years is not enough. On that note, it is clear to every Gambian that the president has no intention to honour the coalition agreement of three years transition. Earlier on these three years, the agreement was challenged by Lawyer Ousainu Darboe, leader of the main opposition party; United Democratic Party (UDP), who said that anyone who asks President Barrow to step down after three years; he will sue the person to a competent court of law. Furthermore, this was a clear manifestation that the changed government's Gambia objectives will either be shattered or far from fetch. Eventually, President Barrow registered his political party called Nation People's Party (NPP) in preparation for the 2021 presidential election in The Gambia.

\title{
Corruption and its practice in New Gambia
}

The research discusses corruption because it has slow down the development and economic growth of The Gambia. Cross violation of human rights is one reason Gambians yearn for change from authoritarian rule to democratic governance. Arguably, Moyo (2009) emphasis that corruption cost Africa billions of dollars every year. Moyo (2009) mentioned that this "negative corruption" drains Africa's public purse dry and does nothing to address its desperate needs. The Gambia is not an exception to this, and in fact, the issue of accountability and transparency is still a challenge in The 
Gambia's current government, which they inherited from the previous governments or regimes. The public expenditure is higher than what the governments earn, and corruption has become the order of the day due to bad governance. Corruption is an endemic problem in The Gambia since the first regime, which has led to several coup attempts. In 1981, there was a coup attempt by Kukoi Samba Sanyang, which almost succeeded in unseating the constitutionally elected government of The Gambia. The government-controlled Sanyang for some hour before Senegalese forces intervened. In a 30 minutes radio broadcast, Sanyang condemned imperialism and neo-colonialism and accused the Jawara government of corruption, tribalism, and mismanagement of public funds, resulting in unemployment and injustice (Sallah 1990).

Furthermore, by 1993, allegations of endemic corruption and nepotism plagued the Jawara government (Loum 2002). In addition, Jawara's government continue to rule up to $22^{\text {nd }}$ July 1994 , when another coup took place and eventually succeeded in overthrowing the legitimate government of The Gambia and the coupes installed themselves to power. The junta also accused the government of Jawara of corruption, nepotism, and mismanagement of public funds, which they promised to eradicate judiciously. Unfortunately, they end up becoming more corrupt than Jawara's regime. When former president Jammeh lost the election to Adama Barrow, a commission of inquiry set up to look into his associates' financial dealings. Upon completion, the commission submitted their report to the president. The government came up with a white paper that stated that over $\$ 300$ Million and over one billion GMD found to be wasted, misappropriated, and diverted by the former president Jammeh.

Furthermore, Jeggan Grey-Johnson of Africa Regional Office and The Open Society Foundation asked in an interview with Chronicle (2019):

"Is this government (Barrow's Government) transparent?"

Grey-Johnson answered in the negative:

"Absolutely they are not transparent."

The second of the year 2018, the government has diluted and diminished the effectiveness of The Gambia Public Procurement Act by basically just expunging the idea that role of the significant tender board would play, whereby any procurements or tenders that are above certain thresholds have to go through the rigour of intensive open competition the criteria of which clearly stated the act. They amended that to now make sure that the procurement process now opened to arbitrariness and discretion.

The Semlex scandal was under investigation by the parliament; however, President Barrow signed a new contract with Semlex. In addition, the president gave 56 pickup vehicles to National Assembly members. According to President Barrow, the vehicles' donor asked to remain anonymous, which is a cross violation of The Gambia Constitution. Chapter XXI, Section 222 conduct for a public officer, Financial, subsection (11) states that a public officer shall not ask for or accept any property or benefits of any kind for himself or herself or any other person on account of anything done or omitted to be done by him or her on the course of his or her duties. The receipt of any gift or benefit from or on behalf of a commercial firm, business enterprise, or a person having or negotiating a contract with the government shall be deemed to be in contravention of this paragraph unless the contrary is established (Gambia Constitution 1997). The president does not adhere to this constitutional provision, which shows that the government is not accountable and transparent to the people. Furthermore, it was reported by The Fatu Network (2018) that the sum of 35 Million GMD was transferred to the account of the First Lady's Foundation bank account by an unknown person, which did not investigate up to date to account for her financial dealings.

\section{Cross violation of human rights and harassment of media or journalist}

Democratic governance promotes and guarantees respect for the rule of law wherein citizens have the liberty to self-expression, which advocates for free media. It also more the general well-being of the people and ensures that fundamental human rights are respected and adhered to (Bevir 2010). What 
is happening in The Gambia in the new dispensation is contrary to the principles and best practices of democratic governance. Ever since the new government came to power in 2017, approximately three people killed by the security personnel, and more than two media houses harassed, and some journalists arrested and are regarded as bad governance.

There was a cross violation of human rights and harassment of journalists as well as media houses. Few months in office, a man was killed in Kanilai Village by the military, and nothing is done about this matter. Another incident occurred in Faraba Village on $18^{\text {th }}$ June 2018, wherein some people lost their lives, and several people sustained injuries, who are still suffering from the consequences of the incident. A commission set up to look into the matters surrounding the incident. When the commission completed its inquiry, a report submitted to the president's office, and decease families compensated; however, justice is still not served in that respect. During this incident, a journalist named Pa Modou Bojang of Digital FM was attacked by security forces for covering the incident, and in the process, his recorder stolen from him (Jobe 2020). In addition, one journalist named Babucarr Sey was arrested and detained at Kanifing Police Station, who subsequently charged with four counts, conspiracy to commit a felony, destruction of private property, unlawful assembly, and use of banner without a permit. Jallow (2017) reported that the charges against Sey amended and reduced to two counts; the state later dropped incitement of violence and prohibition of conduct conducive to peace; however, the reasons for their dropped are still unknown. The issue of old wine in a new bottle has repeated itself. These are the same charges that Jammeh's regime used to charged journalists with, and now this new government has started to bring the same charges against journalists.

Recently, there is a movement called "Three Years Jotna" (it means three years already) which task themselves to remind the president of his promise that he will step down after three years in office, which was his campaign promises. The group was first issued a permit to demonstrate in December 2019 and submit their petition to the government's spokesperson in which they said that the President must honour his campaign promise by stepping down on $19^{\text {th }}$ January 2020. If not, the group promised to go on a protest again. A week later, President Barrow mentioned in an interview with ptvGambia (2019) that he would not step down, and he must fulfil his mandate of five years, preferably three years. The pressure group granted a permit to carry out their peaceful protest on the $26^{\text {th }}$ January 2020; however, the protest turned violent between the protestors and the Police. Several people sustained the injury, and many people got arrested and detained on that day, including the Executive of Operation Three Years Jotna (Jawo 2020). Two radio stations were closed, and the managers of both radios were arrested and detained. The Executive of Operation Three Years Jotna pressure group is currently facing trials at the High Court in Banjul in which they charged with rioting, unlawful assembly, and rioters' demolition of structures of which one of the counts attract life imprisonment (Jawo 2020). In that case, they are remanded at central state prison (Mile 2) since their bail application could not go through.

Many issues indicate the Barrow led government's similarities with that of Jammeh's regime, such as killings without investigation, harassment of media houses or journalists, and arrest and detention of activists, among others. Therefore, many Gambian now agreed that the governance system is not changed though public service reform is taking place and security reform; however, it is very slow to many. The Gambia only achieved a regime change; however, the governance system is far from changing because much evidence indicates that the government is still closed, and access to information is a big challenge.

\section{Conclusion}

It is evident from the study's finding that democratic regime change succeeded; however, democratic system change is far from achieving. It is because of bad governance since the current government is more interested in entrenching themselves to power than adhering to the principle of democracy. The principles of democratic governance are either ignored or violated by the new government. Firstly, the removal of the presidential candidate contestant's age limit (60) from the constitution of The Gambia without following the due process. The appointment of vice president is another cross violation of the constitution, and the use of executive power to dismiss government ministers is 
another thing that Gambians are not expecting in this new democratic dispensation. The worst of all is the killing of people by security officers, yet they are still never brought before a competent court of law, and corruption is rampant in the public sector.

In conclusion, the system change that Gambians yearn for is far from being attained. It requires concerted efforts with a complete overhaul of the system. What The Gambia needs is a competent and servant leader who has the country's interests at heart to lead the positive change required by the people. Most importantly, an attitudinal change is a key to transforming Gambian society. The propagation of respect for the rule of law is a panacea for meaningful development. More so, costcutting is paramount for advanced economic growth and re-investment.

\section{References}

Albers S (2005) The Governance of Collective Action: On governance systems. In: The Design of Alliance Governance Systems. Wiesbaden: Springer Gabler.

Ansell CK (2008) Theories of democratic network governance. European Political Science 7 (4): 460-471.

Ansell CK \& Torfing J (eds) (2016) Handbook on Theories of Governance. Cheltenham, UK: Edward Elgar Publishing.

Axtmann R (2003) Understanding Democratic Politics: An Introduction. New York: SAGE Publications Ltd.

Bache I \& Flinders M (2004) Multi-level governance and the study of the British State. Public Policy and Administration 19 (1):31-51. https://doi.org/10.1177/095207670401900103.

Bevir M (2010) Democratic Governance. New Jersey: Princeton University Press.

Birch J (2012) Collective action in the fraternal transitions. Biology and Philosophy 27 (3):363-380. https://doi.org/10.1007/s10539-012-9312-8.

Burns D \& Worsley S (2015) Navigating Complexity in International Development: Facilitating Sustainable Change at Scale. UK: Practical Action Publishing.

Campbell BK (ed) (2014) Modes of Governance and Revenue Flows in African Mining. UK: Palgrave Macmillan.

Chhotray V \& Stoker G (2009) Governance Theory and Practice: A Cross-Disciplinary Approach. UK: Palgrave Macmillan.

Chronicle GM (2019) Scrutinising The Gambia under President Adama Barrow. [Accessed 1 October 2020]. https://www.youtube.com/watch? $v=y 1 y C D m M p F f 0 \& t=2 s$.

Clark DH (2006) Principles of administrative therapy. The American Journal of Psychiatry 117 (6):506-510. https://doi.org/10.1176/ajp.117.6.506.

Crano WD, Brewer MB, \& Lac A (2015) Principles and Methods of Social Research. New York: Psychology Press Ltd.

Frederickson HG, Smith KB, Larimer CW \& Licari MJ (2012) The Public Administration Theory Primer. Colorado: Westview Press.

Gambia Constitution (1997) Constitution of the Republic of the Gambia.

Gardner AM (2011) Democratic Governance and Non-State Actors. UK: Palgrave Macmillan.

Gellar S (2005) Democracy in Senegal: Tocquevillian Analytics in Africa. UK: Palgrave Macmillan.

Hartmann C (2017) ECOWAS and the restoration of democracy in The Gambia. Africa Spectrum 52 (1):85-99.

Jallow Y (2017) Police amend charges against Baboucar Sey, Foroyaa Newspaper, 18 June. [Accessed 13 March 2020]. https://foroyaa.net/police-amend-charges-against-baboucar-sey/.

Jawo M (2020) 3 years Jotna leaders to appear in court today, The Point, 4 February. [Accessed 1 October 2020]. https://thepoint.gm/africa/gambia/article/3-years-jotna-leaders-to-appear-incourt-today. 
Jeffang K (2019) Janneh Commission Presents Report: Will the President Act? The Chronicle Gambia, 30 March. [Accessed 23 March 2020]. https://www.chronicle.gm/janneh-commissionpresents-report-will-the-president-act/.

Jobe L (2020) Home Digital FM or King FM Radio still closed, Foroyaa Newspaper, 24 February. [Accessed 1 April 2020]. https://foroyaa.net/home-digital-fm-king-fm-radio-still-closed/.

Josh A (2017) One on one: Interview with Adama Barrow, The Gambia's President, TRT World. [Accessed 23 March 2020]. https://www.trtworld.com/video/one-on-one-express/one-onone-interview-with-adama-barrow-the-gambias-president/5a8a8b212783315f58d1152c.

King FM (2019) King FM Gambia. [Accessed 30 September 2020]. https://www.facebook.com/ kingfm.gambia.1.

Lagerspetz E (2016) Social Choice and Democratic Values. Switzerland: Springer International Publishing.

Loum M (2002) Bad governance and democratic failure: A look at Gambia's 1994 coup. Civil Wars 5 (1):145-174. https://doi.org/10.1080/13698240208402498.

Macmillan Dictionary (2020) [Accessed 23 March 2020]. https://www.macmillandictionary.com/ dictionary/british/system.

McKelvey M, Zaring O, \& Szücs S (2019) Conceptualizing evolutionary governance routines: Governance at the interface of science and technology with knowledge-intensive innovative entrepreneurship. Journal of Evolutionary Economics 30 (2020):591-608. https://doi. org/10.1007/s00191-018-0602-4.

Moyo D (2009). Dead Aid: Why Aid is Not Working and How There is a Better Way for Africa. New York: Farrar, Straus and Giroux.

Mudacumura GM \& Morçöl G (2014) Challenges to Democratic Governance in Developing Countries. Switzerland: Springer International Publishing.

Neuman W (2014) Social Research Methods: Qualitative and Quantitative Approaches. UK: Pearson.

Olson M (1965) The Logic of Collective Action: Public Goods and the Theory of Groups. UK: Harvard University Press.

Pal LA (2012) Frontiers of Governance: The OECD and Global Public Management Reform. UK: Palgrave Macmillan.

ptvGambia (2019) Live broadcast an exclusive interview with H.E. President Adama Barrow (PART 2) 26th May 2019. [Accessed 1 October 2020]. https://www.youtube.com/ watch? $\mathrm{v}=2$ PccTlHXpWo.

Reisman D (2015) The Economics of Alfred Marshall. UK: Palgrave Macmillan.

Saine A (2009) The Paradox of Third-Wave Democratization in Africa: The Gambia under AFPRCAPRC Rule, 1994-2008. USA: Rowman \& Littlefield Publishers.

Sallah TM (1990) Economics and politics in The Gambia. The Journal of Modern African Studies 28 (4):621-648. https://doi.org/10.1017/S0022278X00054768.

The Fatu Network (2018) Source of the money deposited into The Fatou Bah Barrow Foundation, 28 August. [Accessed 16 September 2020]. https://fatunetwork.net/source-of-the-money-depo sited-into-the-fatou-bah-barrow-foundation/.

Verwimp P (2013). Peasants in Power: The Political Economy of Development and Genocide in Rwanda. Dordrecht: Springer.

Walliman N (2006) Social Research Methods. London: SAGE Publications Ltd.

Wally O (2018) Dr Ismaila Ceesay detained, The Standard Newspaper, 1 February. [Accessed 30 September 2020]. https://standard.gm/dr-ismaila-ceesay-detained/. 